\title{
ОЦЕНКА СОСТОЯНИЯ РАСТИТЕЛЬНОГО ПОКРОВА ЦЕНТРАЛЬНОЙ ЧАСТИ КУРА-АРАЗСКОЙ НИЗМЕННОСТИ
}

\section{ASSESSMENT OF THE STATE OF VEGETATION COVER OF THE CENTRAL PART OF THE KUR-ARAZ LOWLAND

\author{
K. Gasimova \\ R. Abdiyeva \\ V. Ali
}

Summary. An assessment of the vegetation covers of the central part of the Kur-Araz lowland taking into account the indicators of species richness and hemerobia was carried out. In the study area, 13 characteristic types of communities were identified. $0 \mathrm{n}$ the basis of the collected field material, it was established that ephemeral, shrub, forest communities, as well as communities of the sides of railway tracks and fallows, are characterized by the greatest species diversity. The calculated values of the apophytization index indicate that in pasture communities these indicators are significantly lower than in wetlands and higher than in communities located in the area of direct human impact (in shrub, hollow-meadow, roadsides, railways, channels and fallow lands).

Keywords: Kur-Araz lowland, vegetation, communities, transformation, species composition, biodiversity, hemerobia.

\section{Ввемение}

$\mathbf{X}$ озяйственная деятельность человека всегда сопровождается снижением качественного и количественного состава флоры эксплуатируемых территорий, упрощением структуры и снижением продуктивности растительных сообществ, и заменой их производными вариантами [1]. Поскольку растения могут служить биондикаторами состояния растительности [18], то оценка их альфа-разнообразия и установление статуса гемеробии $[3,13,17]$ можно считать одним из наглядных и эффективных методов. Оценка видового богатства позволяет установить уровень разнообразия и составить представление о состоянии флоры изучаемой местности [19]. Концепция же гемеробии применима для измерения степени воздействия человека на флору, растительность и экосистемы в целом [20, 22]. Суть ее заключается в том, что виды-геме-
Гасымова Хатира Гасан

Аспирант, Институт Ботаники, Национальной Академии Наук Азербайджана, Баку, Азербайджан Xatira1987@gmail.com

Абдыева Рена Тахмазовна

К.б.н., доцент, Институт Ботаники, Национальной Академии Наук Азербайджана, Баку, Азербайджан abdiyeva.rena@mail.ru

Али-заде Валида Мовсум

Д.б.н., профессор, Институт Ботаники, Начиональной Академии Наук Азербайджана, Баку, Азербайджан

vm_alizade@yahoo.com

Аннотация. Проведена оценка растительного покрова Центральной части Кура-Аразской низменности с учетом показателей видового богатства и гемеробии. На исследуемой территории выделено характерных типов сообществ. На основе собранного полевого материала установлено, что наибольшим видовым разнообразием характеризуются эфемеровые, кустарниковые, лесные сообщества, а также сообщества обочин железнодорожных путей и залежей. Рассчитанные величины индекса апофитизации указывают, что у пастбищных сообществ эти показатели значительно ниже, чем у водно-болотистых и выше, чем у сообществ, находящихся в зоне прямого воздействия человека (в кустарниковых, чально луговидных, обочин дорог, железнодорожных путей, каналов и залежей).

Ключевые слова: Кура-Аразская низменность, растительность, сообщества, трансформация, биоразнообразие, гемеробия.

робы принимаются как интегральная мера воздействия вмешательства человека в экосистемы $[23,25]$.

Кура-Аразская низменность (КАН) в географическом отношении является частью Арало-Каспийской низменности, крупнейшим аграрным регионом Азербайджана [6, 9]. На протяжении столетий растительность КАН служила зимними пастбищами для животноводства. В настоящее время большая часть территории занята поливными культурами, постоянно расширяются сельскохозяйственные площади, из-за чего происходит антропогенизация естественной растительности, ее засорение сегетальными (сорно-полевыми) и рудеральными (сорными) видами растений [11]. Bсе эти процессы протекают на фоне аридизации климата. В результате намечаются тенденции нарушения видовой и структурной организации фитоценозов, ведущие к опустыниванию [7]. В свете вышеизложенного 
целью настоящей работы являлось выявление основных групп растительных сообществ Центральной части КАН, оценка их видового разнообразия и степени антропогенной нарушенности.

\section{Материалы и методы}

Центральная часть КАН, включает Кюрдамирский и частично прилегающие к нему Гаджи-Габульский и Уджарский административные районы. Исторически район исследования служит зимними пастбищами. Здесь насчитываются около 60 населенных пунктов, в окрестностях которых в последние годы помимо выпаса осуществляется и другая активная хозяйственная деятельность (организация фермерских хозяйств, расширение инфраструктуры и т.д.). Территорию района пересекают одна из крупнейших рек Закавказья Кура и Верхне - Ширванский водный канал, а также авто и - железнодорожная сеть [6].

Рельеф территории - равнина, в которой встречаются небольшие чалы, представляющие собой понижения различной глубины (до 1,5 м), ширины (от 1 до 3 м) и формы (округлой, продольной). В них скапливается влага атмосферных осадков или периодически поднимающиеся грунтовые воды. В местах произрастания галофитов кустарников, полукустарников и кустарничков наблюдается бугристый солончак. Климат характеризуется мягкой зимой и сухим жарким летом. Годовая сумма осадков составляет в среднем 200-400 мм; среднегодовая температура около $+14,5^{\circ} \mathrm{C}$, среднемесячная температура января $+1,4{ }^{\circ} \mathrm{C}$, июля $+27,3^{\circ} \mathrm{C}$, наиболее жаркий месяц август, когда температура воздуха достигает $+45^{\circ} \mathrm{C}$; число безморозных дней в году колеблется от 235 до 265; влияние моря выражается в увеличении абсолютной влажности воздуха, что благоприятно сказывается на растительности [6]. Значительную часть территории составляют глинистые солончаки с сульфатным и хлоридным типами засоления, индикаторами которых являются растения галофиты кустарники, кустарнички и однолетники. Фрагментарно встречаются лугово-болотистые, серозёмные и лугово-серозёмные почвы, привязанные к окраинам рек и озерец. Для гидротермического режима почвенного покрова характерен короткий по времени весенний влажный период с глубоким увлажнением почвенного профиля зимне-весенними осадками и сопровождающийся активностью синузии эфемеров и эфемероидов и длительный летний жаркий засушливый период с наличием в почвенном профиле плёночно-капиллярных токов и замедлением биологической активности [9]. Полевые наблюдения и сбор материала проводили в 2019 г. в пик массового развития травостоя. Объектами исследования служили естественные сообщества и сообщества синантропизированных местообитаний (населенные пункты, обочины транспортной и железнодорожной сети, ограды, залежи, водные каналы - архи и т.д.). Растительность изучали с применением общепринятых в фитоценологии подходов $[8,12,16]$. Выбирались местообитания с характерной растительностью. По доминантному и видовому составу сообщества разделяли на 13 типов: 1) эфемеровые злаковые (Э3); 2) эфемеровые разнотравно-злаковые (ЭР3); 3) эфемеровые бобово-разнотравно-злаковые (ЭБР3); 4) полынно - солянково - эфемеровые (ПСЭ); 5) солянково-эфемеровые (СЭ); 6) чально-луговидные (ЧЛУ); 7) кустарниковые (КУС); 8) лесные (ЛЕС); 9) водно-болотистые (ВБ); 10) обочин каналов (ОК); 11) сообщества дорожных обочин (ДО); 12) сообщества железнодорожных обочин (ОЖД); 13) сообщества залежей (ЗАЛ). В них закладывались модельные площади размером 100×100 м, на которых проводились стандартные геоботанические описания. Видовое разнообразие оценивали несколькими наиболее популярными индексами: видового богатства Маргалефа $\left(D_{M g}\right)$ и Менхиника $\left(D_{M n}\right)$, Шеннона $\left(H^{\prime}\right)$, выравненности Бергера-Паркера $\left(D_{B P}\right)$, доминирования Симпсона (Ds) $[5,10,15,19]$.

Для изучения гемеробности растительности применялись принципы, предложенные Jalas J. (1955), Schlüeter H. (1987), Frank D. and Klotz S. (1990), Ишбирдиным А.Н. (2012), Ишмурзиной М.Г. (2015) и др. [2, 4, 21, 22, 24]. Зарегистрированные на площадках виды группировали следующим образом. Группа апофитов, включает а-виды (агемеробы) виды естественных сообществ, уязвимые к антропогенному воздействию, овиды (олигогемеробы) виды естественных сообществ, выносящие слабое антропогенное влияние и m-виды (мезогемеробы) виды естественных сообществ, испытывающих экстенсивное антропогенное влияние. Группа антропофитов, включает b-виды ( $\beta$-эугемеробы) виды сообществ, далеких от естественных и устойчивые интенсивной эксплуатации, с-виды (а-эугемеробы) сорные представители природных и антропогенных сообществ, переносящие регулярные и сильные нарушения, р-виды (полигемеробы) - растения, выращиваемые в культуре и типичные рудеральные растения, выносящие сильные и частые нарушения местообитаний; t-виды (метагемеробы) - виды полностью деградировавших экосистем и искусственных сообществ. В зависимости от соотношения гемеробных фракций выделялись стадии антропогенной трансформации: агемеробная - благополучная стадия без воздействия человека; олигогемеробная - стадия слабого воздействия, мезогемеробная - стадия умеренного воздействия, $\beta$-гемеробная - умеренно-сильные воздействия человека, а-гемеробная - сильное антропогенное воздействие, полигемеробная - чрезмерное воздействие человека, метагемеробная - биоценоз разрушен [14]. Для оценки степени трансформации растительных со- 


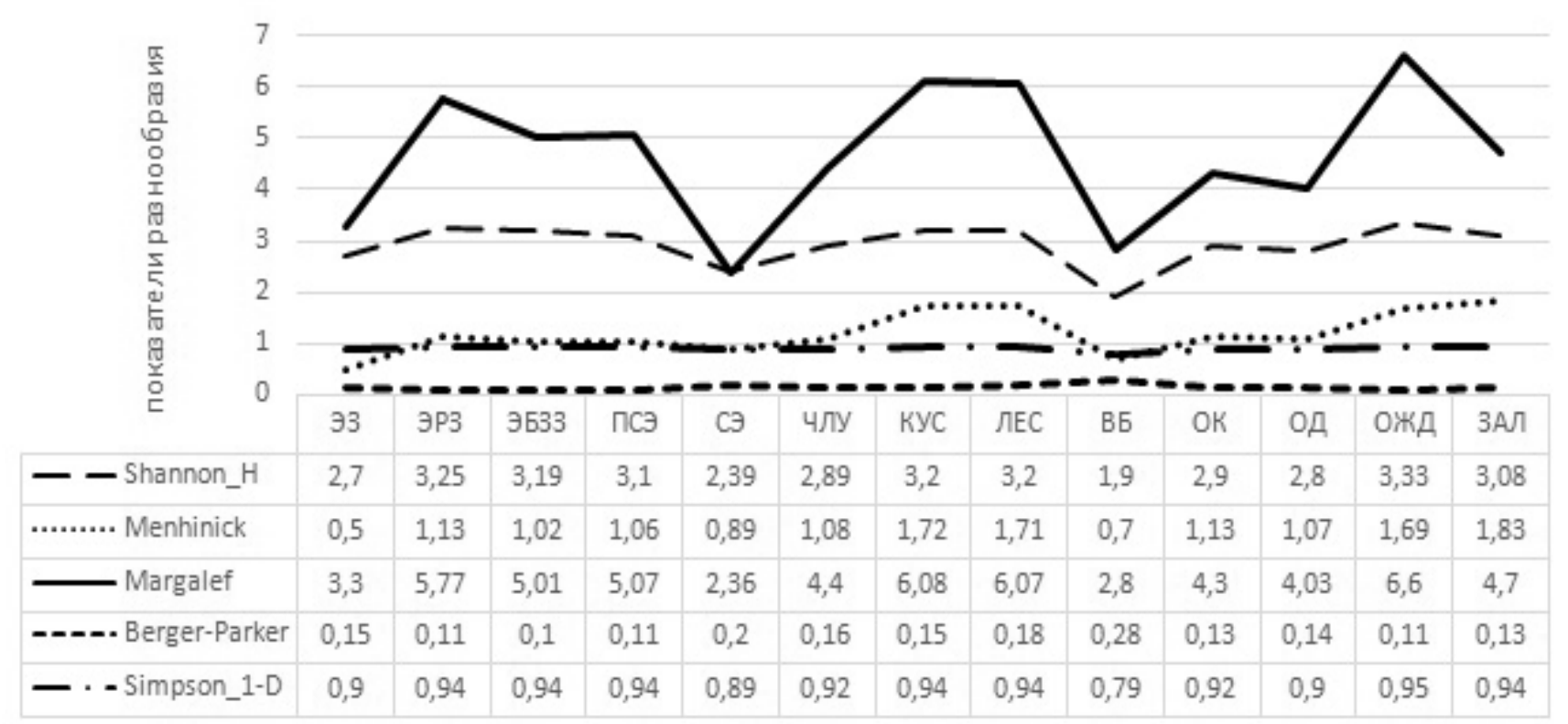

Рис. 1. Показатели видового $\alpha$-разнообразия растительных сообществ.

обществ также рассчитывался индекс апофитизации, т.е. отношение числа апофитов к числу антропофитных видов в конкретном сообществе. Построение дендограмы сходства видового состава сообществ и статистические расчеты проводили в программном обеспечении Past 3. версии Windows 2007 с использованием пакета Microsoft Excel.

\section{Результаты}

В районе исследований нами выделены 13 характерных сообществ. Эфемеровые злаковые - доминанты Bromus rubens L., Echinochloa crus-galli (L.) Beauv., Bromus japonicus Thunb., Lolium rigidum Gaudin, Eremopyrum triticeum (Gaertn.) Nevski, Aegilops cylindrica Host, Hordeum murinum subsp. leporinum (Link) Arcang. и др.; ПП- 90\%). Эфемеровые разнотравно-злаковые - доминанты - Filago pyramidata L., Matricaria recutita L., Senecio leucanthemifolius subsp. vernalis (Waldst. \& Kit.) Greuter, Calendula arvensis (Vaill.) L., Taraxacum desertorum Schischk., E. crus-galli (L.) Beauv., Tragopogon graminifolius DC., A. cylindrica, B. rubens и др.; ПП- 90\%). Эфемеровые бобово-разнотравно-злаковые доминанты - Medicago rigidula (I.) All., M. minima (L.) L., Melilotus officinalis (L.) Pall., T. desertorum, Veronica persica Poir. и др.; ПП- 100\%. Полынно - солянково - эфемеровые - доминанты Artemisia fragrans Willd., Salsola nodulosa (Moq.) iljin, Torularia contortuplicata O. Schulz., T. desertorum и др., ПП- 60\%. Солянково-эфемеровые - доминанты - Kallidium caspicum (L.) Ung. -Sternb., Suaeda dendroides (C.A. Mey.) Moq., Salsola dendroides Pall., Frankenia hirsuta L., Psylliostachys spicata (Willd.)
Nevsky, и др.; ПП- 60\%. водно-болотистые - доминанты Phragmites australis (Cav.) Trin. ex Steud., Alopecurus arundinaceus Poir., Chrysopogon zizanioides (L.) Roberty, Typha angustifolia L. и др.; ПП- 90-100\%. Чально-луговидные - доминанты Alhagi pseudalhagi (M. Bieb.) Desv.ex B. Keller et Shap., Glycyrrhiza aspera Pall., Cichorium intybus L., Limonium meyeri (Boiss.) O. Kuntze и др.; ПП-40\%. Кустарниковые - доминанты Tamarix ramosissima Ledeb., T. Meyeri Boiss., Rubus caesius L., C. intybus, Geranium dissectum L. и др.; ПП-50\%. Лесные - доминанты Salix alba L., Elaeagnus angustifolia L. и др. ПП- 80\%. Сообщества обочин каналов - доминанты Mentha longifolia (L.) L., Mentha aquatica L., Prunella vulgaris L., Elymus repens (L.) Gould, Urtica urens L. и др.; ПП -70\%. Придорожных доминанты $G$. aspera, C.intybus, Plantago lanceolata L., Geranium molle L., Rapistrum rugosum (L.) All., Silybum marianum (L.) Gaertn., Cirsium vulgare (Savi) Ten., Carthamus lanatus L. и др.; ПП- 70\%, железнодорожных обочин - доминанты Atriplex aucheri Moq., Onopordum acanthium L., S. leucanthemifolius subsp. vernalis (Waldst. \& Kit.) Greuter, Petrosimonia brachiata (Pall.) Bunge. и др.; ПП- 60\%, а также сообщества залежей - доминанты Cressa cretica L., S. marianum (L.) Gaertn., C. vulgare, Erigeron canadensis L., Xanthium spinosum L. и др.; ПП- 60\%. Первые 5 относятся к пустынному и полупустынному типам растительности; остальные соответственно к водно-болотистому, мезогалофильному луговому, кустарниковому, лесному и сорному рудерально-сегетальному. Видовое разнообразие растительного покрова характеризуется неравноценностью. Несмотря на некоторые расхождения, связанные с различной чувствительностью рас- 


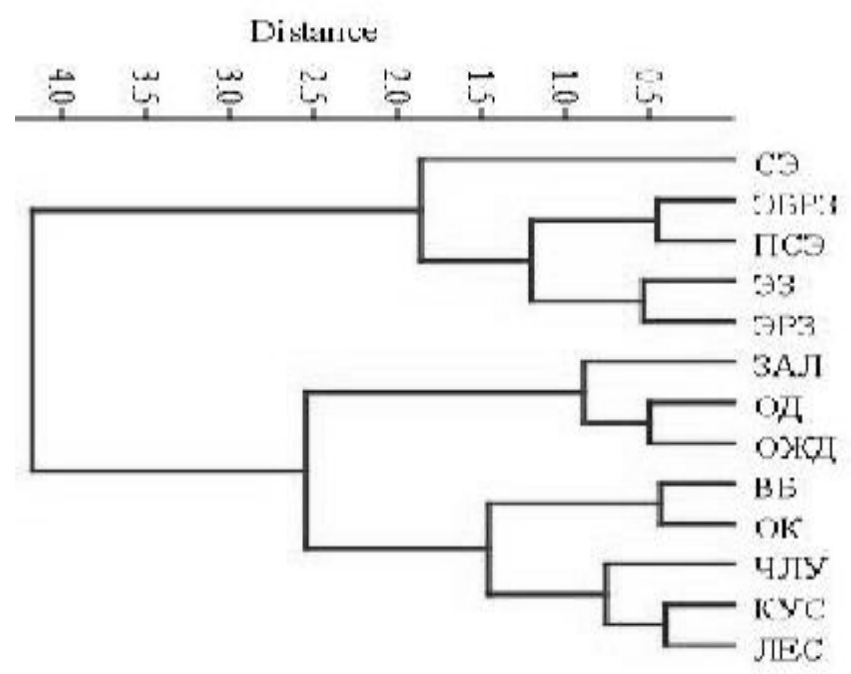

Рис. 2. Дендограмма видового сходства растительных сообществ

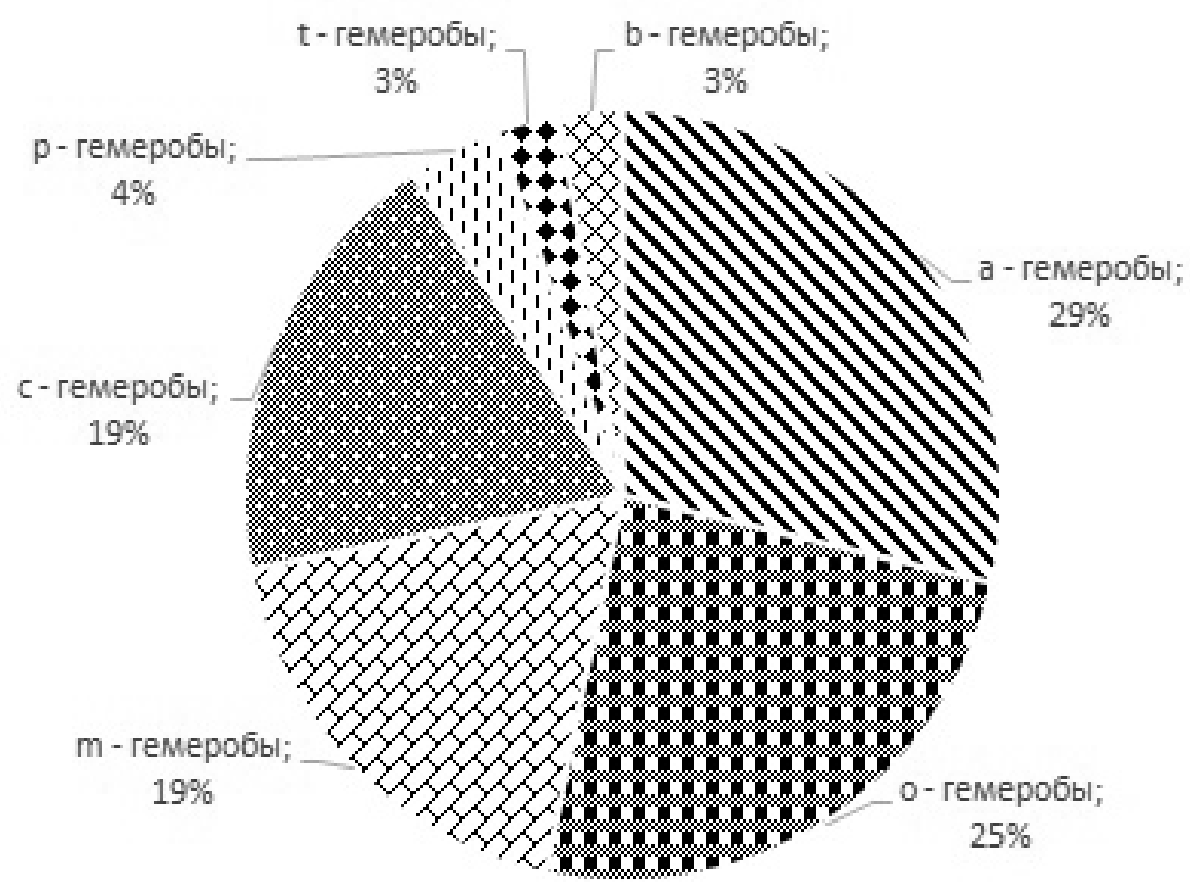

Рис. 3. Общее содержание гемеробных фракций в растительном покрове

считанных индексов, в целом кривые разнообразия характеризуются схожими отрицательными и положительными пиками (рис. 1). Наиболее высокие значения у эфемерово-разнотравно-злаковых (H - 3,25; $\mathrm{Mn}-1,18$; $\mathrm{Mg}$ - 5,77), эфемерово-бобово-разнотравно-злаковых (H -3,19; $\mathrm{Mn}-1,02 ; \mathrm{Mg}-5,01)$, лесных (H -3,2; Mn -1,71; Mg -6,08), кустарниковых (H -3,2; Mn-1,72; Mg - 6,08) сообществ, а также сообществ железнодорожных обочин $(\mathrm{H}-3,33 ; \mathrm{Mn}-1,69 ; \mathrm{Mg}-6,6)$ и залежей $(\mathrm{H}-3,08$; $\mathrm{Mn}-1,83 ; \mathrm{Mg}-4,7)$. У полынно-солянково-эфемеровых (H -3,1; Mn - 0,89; Mg - 5,07), чально-луговидных (H -
2,89; $\mathrm{Mn}-1,08 ; \mathrm{Mg}-4,4)$ и сообществ обочин дорог (H-2,8; Mn -1,07; Mg - 4,03) показатели чуть ниже.

Низким видовым богатством характеризуются солянково-эфемеровые $(\mathrm{H}-2,39 ; \mathrm{Mn}-0,89 ; \mathrm{Mg}-2,36)$ и водно-болотистые (H - 1,9; $\mathrm{Mn}-0,7 ; \mathrm{Mg}-2,8)$. Индекс доминирования во всех сообществах варьирует от 0,1 до 0,2, а индекс выравненности находится в пределах 0,9-0,8, что указывает на нарушенную всех структуру сообществ. Дендрограмма близости видового состава сообществ выделяет 2 группы (рис. 2). Первая объеди- 
Таблица 1. Индекс апофитизации в растительных сообществах

\begin{tabular}{|c|c|c|c|c|c|c|c|c|c|c|}
\hline \multirow{3}{*}{ № } & \multirow{3}{*}{ Сообщество } & \multirow{3}{*}{$\begin{array}{l}\text { Общее число } \\
\text { видов }\end{array}$} & \multicolumn{7}{|c|}{ Фракция гемеробов } & \multirow{3}{*}{$\begin{array}{l}\text { Индекс } \\
\text { апофитизации }\end{array}$} \\
\hline & & & \multicolumn{3}{|c|}{ Апофиты } & \multicolumn{4}{|c|}{ Антропофиты } & \\
\hline & & & a & 0 & m & $b$ & c & $p$ & $\mathrm{t}$ & \\
\hline 1 & $Э 3$ & 34 & 5 & 8 & 12 & 0 & 7 & 1 & 0 & 4.25 \\
\hline 2 & ЭР3 & 58 & 15 & 15 & 14 & 1 & 12 & 1 & 0 & 3.14 \\
\hline 3 & ЭБРЗ & 50 & 12 & 12 & 13 & 2 & 11 & 0 & 0 & 2,84 \\
\hline 4 & ПСЭ & 32 & 10 & 9 & 4 & 0 & 6 & 3 & 0 & 2,6 \\
\hline 5 & $C \ni$ & 18 & 3 & 7 & 5 & 0 & 2 & 1 & 0 & 5,0 \\
\hline 6 & KYC & 39 & 7 & 5 & 10 & 1 & 12 & 2 & 2 & 1,3 \\
\hline 7 & $\mathrm{BD}$ & 15 & 9 & 4 & 2 & 1 & 0 & 0 & 0 & 15,0 \\
\hline 8 & чЛУ & 43 & 3 & 9 & 13 & 0 & 15 & 1 & 2 & 1,4 \\
\hline 9 & ЛЕС & 51 & 12 & 10 & 13 & 2 & 8 & 2 & 4 & 2,9 \\
\hline 10 & ОД & 54 & 6 & 7 & 15 & 2 & 18 & 4 & 2 & 1,1 \\
\hline 11 & ЗАЛ & 42 & 0 & 3 & 11 & 3 & 16 & 5 & 4 & 0,5 \\
\hline 12 & ОЖД & 39 & 3 & 4 & 11 & 0 & 13 & 6 & 2 & 0,85 \\
\hline 13 & OK & 38 & 3 & 9 & 11 & 1 & 10 & 1 & 3 & 1,53 \\
\hline
\end{tabular}

няет естественные пустынные и полупустынные сообщества с полукустарниками, кустарничками и хорошо развитой синузией эфемеров. Сюда входят виды и сообщества, исторически привязанные к засоленным местообитаниям. Вторая разделяется на 2 подгруппы: сообщества естественных (ВБ, ЛЕС, ЧЛУ), полуестественных (ОК, ОЖД) и синантропных местообитаний (ОД, ЗАЛ), находящихся в условиях нормального и умеренного увлажнения и слабой засоленности субстрата.

Из 152 видов, зарегистрированных в растительных сообществах более половины (71\%) приходится на долю апофитов. Из них а-гемеробы составляют 28\%; o, m - фракции, соотвественно - 24\%, 19\%. Из антропофитов большинство составляют с - гемеробы (19\%), на остальные же группы приходится по 3-4\% (всего 29\%) (рис. 3).

Однако нужно отметить, что доля апофитов распределяется по растительным сообществам неравномерно. В одних из них эти виды представлены обильно, а в других присутствуют незначительно, либо вообще отсутствуют.

Сообщества обочин каналов, дорог, залежей и железнодорожных путей, находящихся в зоне прямого антропогенного влияния, характеризуются преобладанием с - гемеробов. Поэтому их можно охарактеризовать как находящиеся на эугемеробной стадии трансформации (сильное воздействие человека). Они, как правило, являются очагами размножения для сорных и в том числе инвазивных растений. Наиболее благополучными можно считать водно-болотистые сообщества, находящиеся на агемеробной стадии (без воздействия человека) и солянково-эфемеровые сообщества - огемеробная стадия (слабое воздействие человека). Рассчитанные индексы апофитизации имели следующие значения: у эфемерово-злаковых - 4,25, эфемерово-злаково-разнотравных - 3,14, солянково-эфемеровых - 5,0, эфемерово-бобово-злаково-разнотравные - 2,84, полынно-солянково-эфемеровых 2,6, низинных лесов - 2,9. У сообществ, находящихся в зонах прямого контакта с человеком (кустарниковые, чально-луговидные, сообщества обочин дорог, железнодорожных путей, каналов и залежей значения составили) индекс апофитизации имеет значение 0,5-1,2. Самый высокий индекс у водно-болотистых сообществ - 15,0. (табл. 1).

\section{Обсужление}

На исследуемой нами территории эфемеровые злаковые, эфемеровые разнотравно-злаковые, эфемеровые бобово-разнотравно-злаковые сообщества составляют основную травянистую массу растительного покрова. Как следует из названий, одни из них образуются исключительно злаками с единичным присутствием разнотравья, другие, разнотравно-злаковые, на ряду, со злаками включают разнотравных представителей. В бобово-разнотравно-злаковых сообществах основная доля приходится на виды бобовых из родов Medicago L., Trifolium L., Melilotus Mill. Встречаются также варианты эфемеров с видами солянок и полынью. Число видов в этих сообществах может достигать 20-25, а ПП зависит от количества выпадающих в ранневесенний период осадков и может достигать 90-100\%. С повышением же температуры воздуха оно сокращается в 2-3 раза и в последней декаде мая си- 
нузия эфемеров полностью выгорает. По хозяйственному значению перечисленные сообщества являются кормовыми угодьями, в которых также встречаются красильные, лекарственные и другие полезные группы растений. Поэтому они являются наиболее уязвимыми к антропогенному воздействию.

Следующей по территориальной значимости является водно-болотистая растительность (Phragmiseta), которая размещается вдоль прибережья р. Куры, в акватории каналов, в окрестностях небольших мелких озер, а также многочисленных мелких болотистых участков, образованных в местах высокого залегания грунтовых вод. В кустарниковом типе доминируют виды родов гребенщик, тамарикс (T. ramosissima и T. meyeri) и ежевики ( $R$. caesius). Гребенщики в районе исследования произрастают в различных экологических условиях от пресных почв до засоленных с различным режимом увлажнения. Однако больше тяготеют к слабо засоленным местам с повышенной увлажненностью или высоко залегающими грунтовыми водами. В настоящее время они являются неотъемлемым спутником прибрежной растительности, замещая остаточные от вырубки низинные леса. Поскольку район исследования изобилует чалами и другими отрицательными формами микрорельефа, то здесь формируется специфичная чально-луговидная растительность, в составе которой доминируют мезофильные представители разнотравных многолетников и кустарников. Формирование и развитие этой растительности определяется экологическими условиями их местообитания. Они приурочены к понижениям микрорельефа, где для них создаются благоприятные условия. В основном она привязана к солонцевато-солончаковым и лугово-серо-земным почвам. В районе исследования в настоящее время формируется новый вариант леса - адвентивный, который является следствием некогда активно проводившейся интродукции древесных видов Ailanthus altissima (Mill.) Swingle и Robinia pseudoacacia L. Образующиеся в таких местах труднопроходимые заросли постепенно вытесняют Populus canescens (Ait.) Smith. и другие древесные виды. Сообщества обочин каналов, дорог и железнодорожных путей, а также залежей нельзя назвать абсолютно сорными, но и к естественно-природным сообществам их уже отнести нельзя, т.к. наравне с видами естественной флоры - A. pseudalhagi, Cynodon dactylon (L.) Pers., G. glabra, Ph. australis, P. x canescens, S. dendroides, Stellaria holostea L., Matricaria matricarioides (Less.) Porter и др. в равной степени в них присутствуют рудеральные растения Sonchus olerace a L. ,Sonchus asper (L.) Hill., H. murinum subsp. leporinum, S. leucanthemifolius subsp. vernalis, $S$. vulgaris L, Persicaria lapathifolia (L.) Delarbre, Carduus pycnocephalus subsp. marmoratus (Boiss. \& Heldr.) P.H. Davis и инвазивные виды $A$. altissima, $R$. pseudoacacia, $X$. strumarium, X. spinosum,
Chenopodium album L., Arundo donax L., Amaranthus retroflexus L. и др.

Оценка видового разнообразия показала, что наиболее высокие значения у эфемерово-разнотравно-злаковых, эфемерово-бобово-разнотравно-злаковых, лесных, кустарниковых сообществ, а также сообществ железнодорожных обочин и залежей. У полынно-солянково-эфемеровых, чально-луговидных и сообществ обочин дорог показатели чуть ниже. Низким видовым богатством характеризуются солянково-эфемеровые и водно-болотистые сообщества, что, скорее всего, связано с экологическими условиями их местообитания. В первом случае это высокая засоленность почв, индикаторами чего являются такие галофиты как Halocnemum strobilaceum (Pall.) M. Bieb., Salsola dendroides Pall., Suaeda dendroides (C.A. Mey.) Moq., а также индикаторы вторичного засоления Climacoptera crassa (M. Bieb.) Botsch., Petrosimonia brachiata (Pall.) Bunge. Во втором же причиной является высокая гигрофитность и гидрофитность субстратов, ограничивающих возможность проникновения сюда других экологических групп и создающих межвидовую конкуренцию за среду обитания. Сообщества с высокими и средними значениями индексов, как правило, достигают этих показателей за счет хорошо развитой синузии эфемеров.

Видовой состав изученных сообществ представлен как апофитами так и антропофитами, проникшими сюда в результате хозяйственной деятельности человека. Однако доля участия и соотношение между ними различаются. Анализ соотношения гемеробных групп показал, что растительности преобладают виды, выдерживающие умеренное антропогенное воздействие (m -гемеробы) и виды, выносящие регулярные и сильные нарушения ценозов (с-гемеробы), что свидетельствует об слабо удовлетворительном состоянии (рис. 5). Эти группы при продолжающимся бессистемном выпасе крупного и мелкого рогатого скота, сенокосе, проводимом в период цветения травостоя и организации все новых фермерских хозяйств, в ближайшем будущем увеличит свою численность и качество видового состава растительных сообществ снизится. Фракции а- о-гемеробов имеют подчиненное значение: а-гемеробы составляют основу водно-болотистых сообществ, о-гемеробы полынно-солянково-эфемеровых, солянково-эфемеровых и частично присутствуют в водно-болотистых и чально-луговидных. Таким образом, наиболее благополучными в отношении синантропизированности можно считать малодоступные и значительно удаленные от населенных пунктов водно-болотистые сообщества, находящиеся на агемеробной стадии (без воздействия человека) и развивающиеся на солончаках полынно-солянково-эфемеровые и солянково-эфемеровые сообщества - оге- 
меробная стадия (слабое воздействие человека). Сообщества обочин каналов, дорог, железнодорожных путей и залежей, находящихся в зоне прямого антропогенного влияния, характеризуются преобладанием с - гемеробов, т.е. находятся на эугемеробной стадии трансформации (сильное воздействие человека). Последние, как правило, являются очагами размножения для сорных и в том числе инвазивных растений.

\section{Выво $\triangle \mathrm{b}$}

Сообщества Центральной части КАН имеют разную степень видового разнообразия и синантропизации.
На их показатели оказывают влияние почвенные условия (засоленность, режим увлажнения) и деятельность человека. В связи с постоянным расширением заброшенных, нарушенных и замусоренных экотопов повсеместно встречается и прогрессирует рудерально - сегетальная растительность, которая активно внедряется в антропогенно трансформированные территории - пастбища. Проведенное исследование показало, что растительный покров территории требует дальнейших исследований и разработки мероприятий по восстановлению флоры путем подсева семян в природе, а также интродукции ценных кормовых, пищевых, лекарственных и других видов растений.

\section{ЛИТЕРАТУРА}

1. Горчаковский П.Л., Харитонова О.В. Синантропизация растительного покрова Печоро-Илычского Биосферного заповедника в высотном градиенте. Экология. 2007. № 6. С. 403-408.

2. Ишбирдин А.Р. Анализ парциальных флор прибрежно-водных сообществ Якутии по степеням гемеробии // Изв. Самар. науч. центра РАН. 2012. Т. 14, № 1 (17). С. 1812-1815.

3. Ишмуратова М.М., Ишбирдин А.Р., Суюндуков И.В. Использование показателя гемеробии для оценки уязвимости некоторых видов орхидей Южного Урала и устойчивости растительных сообществ // Биологический вестник. 2003. Т. 7. № 1-2. С. 33-35.

4. Ишмурзина М.Г., Барлыбаева М.Ш. Гемеробиальность синантропных и синантропизированных сообществ южно-уральского заповедника. Вестник Удмуртского Университета. сер. Биология. Науки о Земле. 2015. Т. 25. № . 2. С. 77-81.

5. Лебедева Н.В., Дроздов Н.Н., Криволуцкий Д.А. Биологическое разнообразие. М.: Гуманит. изд. центр ВЛАДОС. 2004.432 с.

6. Мамедов Г. Национальный Атлас Азербайджанской Республики, Баку. 2014. 244 с. (на азерб.яз.)

7. Мансимов М.Р. Воздействие изменения климата на процессы опустынивания в Азербайджане. Водная Конференция. Санкт-Петербург. 2019. С. 56-61.

8. Миркин Б.М., Наумова Л.Г., Соломец А.И. Современная наука о растительности. М.: Логос. 2001. 261 с.

9. Мусеибов М.А. Физическая география Азербайджана. Баку. 2000. 47 с. (на азерб.яз.)

10. Мэгарран Э. Экологическое разнообразие и его измерение. М.: Мир. 1992. 184 с.

11. Набиева Ф.Х. Процесс опустынивания в Кура-Араксинской низменности и Приараксинской равнинах и его влияние на биоразнобразии флоры. автореф. дис., докт. биол. наук. Баку. 2017. 1-50 с. (на азерб.яз.)

12. Шенников А.П. Введение в геоботанику. 1964. 447 с.

13. Dymond J.R., Stephens P.R., Newsome P.F., Wilde R.H. Percentage vegetation cover of a degrading rangeland from SPOT // International Journal of Remote Sensing. 1992. Vol. 13. N. 11. P. 1999-2007.

14. Jackowiak B. The hemeroby concept in the evaluation of human influence on the urban flora of Vienna // Phytocoenosis. 1998. Vol. 10. P. 79-96.

15. Jost L. Partitioning diversity into independent alpha and beta components // Ecology. 2007. Vol. 88, N. 10. P. 2427-2439.

16. Pedrotti F. Plant and Vegetation Mapping (Geobotany Studies) 2013 edition by Springer-Verlag Berlin Heidelberg. 2013. Vol. 5, N. 3. P. 275.

17. Steinhardt U., Herzog F., Lausch A., Müller E., Lehmann S. Hemeroby index for landscape monitoring and evaluation. — In: Pykh, Y.A., Hyatt, D.E., Lenz, R.J. (eds) // Environmental Indices — System Analysis Approach. 1999. 0xford, E0LSSPubl., P. 237-254.

18. Walz U., Stein C. Indicators of hemeroby for the monitoring of landscapes in Germany // Journal for Nature Conservation. 2014. Vol. 22, N. 3. P. $279-289$.

19. Whittaker R. Evolution and measurement of species diversity // Taxon. 1972. Vol 21. P. 213-251.

20. Blume H.P. \& Sukopp H. Ökologische Bedeutung anthropogener Bodenveränderungen // Schriftenreihefür Vegetationskunde. 1976. Vol. 10. P. 75-89

21. Frank D., Klotz S. Biologisch-oekologische Datenzur Flora DDR. Martin Luther Universitaet, Halle — Wittenberg. 1990. 167 p.

22. Jalas J. Hemerobe und hemechore Pflanzenarten // Einterminologischer Reformversuch, ActaSocietatis pro Fauna et Flora Fennica. 1955. Vol. 72, N. 11. P. 1-15.

23. Kowarik, I. Zummenschlichen Einfluss auf Flora und Vegetation: The oretische Konzepte und ein Quantifizierungsansatz am Beispiel von Berlin (West) // Landschaftsentwicklung und Umweltforschung. 1988. N56. P. 1-280.

24. Schlüter H. Vegetationsmerkmalezur Kennzeichnung und Bewertung von Hemerobie und okologischer Stabilität. Erfassung und Bewertungantropogener Vegetationsveränderungen. Teil. II. Wiss. Beitr. Martin-Luter-Univ. 1987. 25. P. 13-19.

25. Sukopp H. Dynamik und Konstanz in der Flora der Bundesrepublik Deutschland. // SchriftenreihefürVegetationskunde. 1976. N10. P. 9-26.

(с Гасымова Хатира Гасан ( Хatira1987@gmail.com ), Абдыева Рена Тахмазовна ( abdiyeva.rena@mail.ru ),

Али-заде Валида Мовсум ( vm_alizade@yahoo.com ).

Журнал «Современная наука: актуальные проблемы теории и практики» 